\title{
Predicting Turnover Intention Among Pharmaceutical Employee Through Psychological Contract Fulfillment For Work Engagement
}

\author{
Daniel Kisahwan*, Andreas Wahyu Gunawan \\ Faculty of Economics and Business \\ Universitas Trisakti \\ Jakarta, Indonesia \\ *kisahwand@gmail.com
}

\begin{abstract}
The aim of this study is to analyze the implication of psychological contract fulfillment on employee's turnover intention through work engagement. Data sample were collected from 240 employees foreign pharmaceutical industry in Indonesia. Data analysis using the Structural Equation Model. The data collection is merely based one shoot study. The finding show that Both of psychological contract fulfillment dimension transactional and relational plays a significant predictor for turnover intention. They will determine how changes turnover intention through work engagement. At the end of the year the tendency of employee involvement is high due to the high pressure of the company to achieve targets and direct performance bonuses for the targets achieved. Limited function effect of psychological contract fulfillment on turnover intention in Indonesian pharmaceutical companies. This research gives significant contribution to the literature on theories regarding employee work engagement and turnover intention in the Indonesian context.
\end{abstract}

Keywords-turnover intention, pharmaceutical employee, psychological contract fulfillment, work engagement

\section{INTRODUCTION}

The pharmaceutical business has changed over the year, marked by competitive market and external influence. Nowadays, industry companies are no longer offer a lifetime employment, personal achievement, and loyalty to the company [1]. The problem in providing employment relation is to connect both employee and employer obligation needs of employees and organizations. Few studies stipulate that altering employee and organization relationship nature will result changes in psychological contract [2]. Psychological contract fulfillment (PCF) is employees' belief of mutual obligations between them and employers [3]. Employees believe that organization will fulfill their needs (e.g. employment and career opportunities) when they accept a position or reject other employment offers. This psychological contract creates employees to be an active participants in the organization in which leads to organizational effectiveness
$[4,5]$. Employees will likely to be loyal to the organization when the employers fulfill its obligations [6].

Employees who perform well in the organization will have a higher expectation of their organization in which leads to have a better psychological contract with the organization due to their bigger contribution. As a result, engaged and attached employees will do twice hard work than the low engagement employees. Conversely, Bal et al. [7] PCF is related to a higher level of work engagement. The dynamic of PCF refer to social exchange theory (SET) [8]. The employee will try to work as well as possible and hope of getting a good reply from the company [9].

Turnover intention from professional perspectives regarding as personal identity in daily work li [10]. Following Guerrero et al. [10] use of cognitive dissonance test (CDT), elaborate the self-belief about work experience and willingness. Research in the field of human resource management (HRM) is not only about psychological contact and work involvement [11] but an understanding of ongoing professional engagement and turnover intention (TI) [12]. Turnover rate impact to the cost of recruitment and working spirit, weaken the intellectual capital, and inhibit sustained and health development of enterprises. The explanation of the variables that affect employee turnover intentions has received widespread attention among academics and practitioners

Three variables affect employee turnover intentions: 1) Personal characteristics among age, seniority, gender, marital status, education level, income; 2) Characteristics of work, work environment and organization: such as organizational culture, organizational support, organizational justice, organization integration and working condition, work load, and work autonomy; 3) Organization external factors: such as employment opportunities and labor market conditions. The increasing explanation of turnover intentions is based on the perspective of psychological contracts that are formulated in stages and have become a characteristic of HR management research [13]. A view Researchers believe in PCF's direct impact on employee turnover intention [14], but some 
researchers have different view. As the conclusion, It is important to verify the PCF as a predictor for TI through work engagement $[7,15,16]$. Turnover intention is as a phenomenon that requires solution. Research to obtain explanation on turnover intention is necessary. Results of the research can be used as a framework to solve turnover intention. The research objective is to obtain explanation on turnover intention among pharmaceutical employee through psychological contract fulfillment for work engagement.

\section{LITERATURE REVIEW}

Work engagement as an obligation from the employer that must be fulfilled. PCF in relation with higher work engagement and lower turnover intention, but only for employees with short period [7]. PCF develops through an interaction process between employees and employers, which comes into force during recruitment but can be influenced by a number of human resource practices [17]. Bakker and Albrecht [18] most of research pointed to differences in WE as a function of conditions, Individual characteristics, and behavior. PCF defined it as an individual's belief in mutual obligations between the person and other parties such as the employer (either the company or someone else), as a set of promises or obligations that can be enforced legally between employer and employee [19], as affective response, behavior and cognitive toward organizational change [20]. PCF is an option to manage employee turnover intention [21]. PCF focuses on the nature of promise related to the exchange relationship includes promises made explicitly and implicitly [22,23]. $P C F$ dimension in accordance with the concept used as a reference Rouseau [24]. $P C F$ dimension in terms of relational and transactional. $P C F$ is increasingly attracting attention, especially when there is a dynamic change in the company. PCF in which each party in that exchange reciprocates the other party's contribution [8]. There is an "obligation nature" of psychological contracts that is far stronger than generic perceptions about social.

H1: Psychological contract fulfillment affects work engagement

Work Engagement (WE) as an employee's effort to carry out the tasks and responsibilities by using self-expression, cognitive and emotion [25]. Work Engagement and employee engagement have the same characteristics and forming aspects [26]. Work Engagement as a condition where a person has positive thoughts so that she/he is able to express herself/himself physically, cognitively and affectively in doing her/his work [27,28]. Work Engagement is a situation which related to a positive, satisfying, motivational welfare affective work [29], an individual condition related to work welfare and therefore does not require external manifestations to develop [30]. Extended research on previous work engagement that showed contribution and climate of organizational [31].

PCF is relation with interesting work content [32]. Social atmosphere is negatively connected with intention to leave job. A number of studies prove relation between psychological contracts in employees' behavior [7,32]. PCF reduces employee's TI $[14,19]$. PCF did not have a significant impact on job satisfaction, organizational commitment, or intention to migrate for employees who were sent through employment agencies [21]. Bal [7] confirms that PCF is related with higher work engagement and lower turnover intention, this only applies to employees with shorter work period. Unfulfilled of psychological contracts is a negative statement follows with intention to leave the organization. Psychological contracts on employee attitudes and behaviors such as intention to leave an organization [33]. Xiong and Wang [21] proposed that organization failure in fulfilling psychological contracts will trigger intention to leave.

\section{$\mathrm{H} 2: \mathrm{PCF}$ affects the turnover intention}

The position of turnover intention on the real behavior of employees [20]. Intention to Leave' is a logical step at work [34]. TI as a dynamic strength for resign [35]. Turnover intention (TI) is an individual intention to leave his organization within a certain time period [19]. The subjective probability is that a person will leave himself or herself from organization within a certain period of time" [5], related to turnover intention. The change in turnover intention, Intention to leave is the interest to permanently and voluntarily resign from the organization [36]. Work Engagement as a mediator for turnover intention [37]. Work engagement has been linked to turnover intention [27]. Highly involved employees usually have already accumulated a lot of resources, and stronger dedication [38]. Work engagement has been linked to turnover intentions [27].

H3: work engagement affects the turnover intention

\section{METHODS}

Descriptive verification method with a survey of 240 pharmaceutical employees who were randomly selected. SEM tools analysis which based on the covariant was used to analyze the data. The measurement of PCF refers to Xiong and Wang [21], Rouseau [24], Blomme et al. [39], both of dimensions are 1) relational, 2) Transactional. Work engagement measurement was carried out using the Utrecht Work Engagement Scale (UWES)-[18,23,26,40-42]. Turnover intention is measured based on the integrative concept of behavior development predictions from planned behavior theory [43]. 3 items related to how often to consider leaving at the last 6 months job, how much is the probability of leaving and active behavior to find another job [44].

\section{RESUlTS AND DISCUSSION}

In line with Schaufeli and Bakker [27], Soares and Mosquera [30] Psychological Contract Fulfillment the value factor weights 1) Job content $(0.775)$, 2) Development opportunities (0.797) 3) Job security (0.742), 4) Intraorganizational mobility (0.755) 5) Work-family balance (0.759), 6) Atmosphere employment (0.798), 7) Autonomy, (0.712), 8) Salary (0.838) 9) Performance related payments $(0.825)$, 10) Clear job descriptions (0.807) and 11) Broader 
promotional opportunities (0.747). The highest dimension is transactional. This result is in line with the indicators which are put forward with different value factor weights. In general, employees get performance benefits based on work performance or target achievement. Average Variance Extracted is 0.607 , which means that on average $60.6 \%$ of the information contained in each of these indicators. Nonfulfillment of psychological contracts causes changes in employee behavior at work.

In the WE indicators, in accordance with the developed construction of UWES scale, the value weights of each indicator for the Vigor dimension 1) Feeling full of energy for work (0.737), 2) Excitement (0.740). On the dimension of Dedication 1) Work is so challenging $(0.795), 2)$ Work is inspiring (0.765), 3) Enthusiastic about work (0.735), 4) Job pride $(0.705), 5)$ Finding meaning and purpose of work, $(0.757)$ on dimensions Absorption 1) Drifting / drifting while working $(0.8), 2)$ Difficult to separate from work $(0.707$. AVE value is $55, \%)$. Transactional dimension as observed variables with the highest value factor weights is also as an dimension of employees who have a high WE. This shows that providing work content, salary, performance related payment, clear job are very important for employees. But in the other side financial company is limited. Fortunately, the economic situation and competitive in work force are not supported to make a good transactional to employee. Company must get balancing bargaining to increase WE. Strategic WE cannot be separated from the success of the company in building a system of HR functions for psychological contract fulfillment and focus to develop relational dimension better than transactional. It is in line with Bakker and Albrecht [18], Soares and Mosquera [23], Schaufeli et al. [26] and Gupta et al. [41] about dimensions and indicators for Work Engagement.

The value factor weights for TI indicators is how often to consider leaving the last 6 months with a value factor weights (0.903), how much is the likelihood of leaving (0.863) and active behavior to find another job (0.841). AVE value is 0.78 . The fit between attitude and feeling determines how the next behavior will be. Employees tend to change attitudes and affective to reach consonants. But not infrequently that those three indicators are consistent. The results of the structural model test are as follows.

TABLE I. GOODNESS OF FIT

\begin{tabular}{|l|l|l|l|}
\hline \multirow{2}{*}{ Goodness } & \multicolumn{3}{|c|}{ The Result of the Structural Model } \\
\cline { 2 - 4 } & $\begin{array}{c}\text { Cut of } \\
\text { Value }\end{array}$ & $\begin{array}{c}\text { The result of } \\
\text { experience }\end{array}$ & Conclusion \\
\hline $\begin{array}{l}\text { Significance } \\
\text { Probability }\end{array}$ & $\geq 0.05$ & 0.00 & Marginal Fit \\
\hline RSMEA & $<0.08$ & 0.093 & Marginal Fit \\
\hline GFI & $\geq 0.90$ & 0.751 & Poor \\
\hline AGFI & $\geq 0.90$ & 0.697 & Poor \\
\hline CMIN/DF & $\leq 2$ or $\leq 3$ & 3.0 & Fit \\
\hline TLI & $\geq 0.95$ & 0.872 & Marginal Fit \\
\hline CFI & $\geq 0.95$ & 0.885 & Marginal Fit \\
\hline PNFI & $\geq 0.6$ & 0.752 & Fit \\
\hline IFI & $\geq 0.90$ & 0.886 & Marginal Fit \\
\hline
\end{tabular}

CMIN / DF values which are fit, CMIN value is 3, PNFI which shows the test results $>0.6$, that is 0.744 , means fit and other values that support (marginal fit/values that are close to the standard) modification of the model so that this model can be accepted. Modifications as proposed by Arbuckle et al. [45]. The main focus is to increase the influence on indicators 3) Security, 4) Intra-organizational mobility 5) Work-family balance, 6) Work atmosphere, 7) Autonomy, 8) Salary 9) Payments related to performance, 10) A clear job description with a clear system guarantee integrity to guarantee psychological contract fulfillment. The system as an integrated system in HR management. The company shows a high commitment on the ethical side to carrying out HR functions to ensure PCF. The system was designed not only as stated by Ulrich [46] and Rousseau and Greller [47] on how to make contracts that function and can be stored in organizations. The system illustrates the position of HR governance as a strategic partner of the company [48]. New concept about how the function and role of HR as a key to a system that guarantees psychological contract fulfillment of employees.

The modification results show that GOF values are better such as RMSEA (0.066). GFI (0.851) AGFI > 0.763, CMIN is 2.002. TLI values are 0.936 , CFI (0.947), PNFI (0.741). IFI value of 0.948 in general the model complies with observations. The direct effect of PCF on WE is 0.767 and the effect of WE on turnover intention is -0.795 . The direct effect of psychological contract fulfillment on TI is 0.090. In line with Bal et al. [49] which confirms that PCF is related to WE and turnover intention [21,27,30,38].

\section{CONCLUSION}

The use of individual epistemology to obtain data can lead to bias. Length of work, type of work, personal demographic characteristics are considered homogeneous and can increase of bias in measurement and estimation. Work Engagement can be used as a predictor for TI. WE is influenced by psychological contract fulfillment. HRM as a strategic partner focuses on improving the relational dimension to improve PCF. There is pressure both competition in the pharmaceutical industry and the bleak economic future of the trade war.

\section{REFERENCES}

[1] A. Tyagi and R.K. Agarwal, "Emerging employment relationships: issues and concerns in psychological contract", The Indian Journal of Industrial Relations, Vol. 45 No. 3, p. 381-395, 2010.

[2] D. Guest, "Flexible employment contracts, the psychological contract and employee outcomes: an analysis and review of the evidence," International Journal Of management Review 5-6 (1) page 1-19, 2014

[3] D.M. Rousseau and S. Tuoriwala "Assessing psychological contracts: Issues, alternatives and measures," Journal of Organizational Behavior, 19, 679-695, 1998.

[4] P.M. Bal, A.H. De Lange, P.G.W. Jansen and M.E.G. Van Der Velde, "Psychological contract breach and job attitudes: A meta-analysis of age as a moderator," Journal of Vocational Behavior, vol. 72, no. 1, pp. 143158, 2008. 
[5] H. Zhao, S.J. Wayne, B.C. Glibkowski and J. Bravo, "The Impact Of Psychological Contract Breach On Work-Related Outcomes: A Meta-Analysis," Personnel Psychology, vol. 60, no. 3, pp. 647-680, 2007.

[6] D.M. Rousseau, "Psychological contracts in organizations", Understanding Written and Unwritten Agreements, CA: Sage, Thousand Oaks, 1995

[7] P.M. Bal, R. De Cooman, and S.T. Mol, "Dynamics of psychological contracts with work engagement and turnover intention: The influence of organizational tenure," European Journal of Work and Organizational Psychology, vol. 22, no. 1, pp. 107-122, 2013.

[8] P.M. Blau, Exchange and power in social life - With a new introduction by the author (1986 ed.). New Brunswick, NJ: Transaction Publishers, 1964.

[9] J.N. Kurtessis, R. Eisenberger, M.T. Ford, L.C. Buffardi, K.A. Stewart, and C.S. Adis, "Perceived Organizational Support: A Meta-Analytic Evaluation of Organizational Support Theory," Journal of Management, vol. 43, no. 6, pp. 1854-1884, 2015.

[10] S. Guerrero, D. Chênevert, and S. Kilroy, "New Graduate Nurses' Professional Commitment: Antecedents and Outcomes," Journal of Nursing Scholarship, vol. 49, no. 5, pp. 572-579, 2017.

[11] A.U. Agarwal, "Linking justice, trust and innovative work behavior to work engagement," Personnel Review, vol. 43, no. 1, pp. 41-73, 2014.

[12] W. oloney, P. Boxall, M. Parsons, and G. Cheung, "Factors predicting Registered Nurses' intentions to leave their organization and profession: A job demands-resources framework," Journal of Advanced Nursing, vol. 74, no. 4, pp. 864-875, 2017.

[13] S.L. Robinson, M.S. Kraatz, and D.M. Rousseau, "Changing obligations and the psychological contract: a longitudinal study", Academy of Management Journal, Vol. 3 No. 1, pp. 137-152, 1994.

[14] W.H. Turnley, and D.C. Feldman, "Psychological contract breach during corporate restructuring", Human Resource Management, Vol. 37 No.1, pp. $71-83,1998$

[15] S.L. Robinson and E.W. Morrison, "The development of psychological contract breach and violation: a longitudinal study," Journal of Organizational Behavior, vol. 21, pp. 525-546, 2000

[16] A.G. Tekleab, R. Takeuchi, and M.S. Taylor, "Extending the chain of relationships among organizational justice, social exchange, and employee reactions: The role of contract violations," Academy of Management Journal, vol. 48, pp. 146-157, 2005.

[17] R.J. Blomme, A. van Rheede, and D.M. Tromp, "The use of the psychological contract to explain turnover intentions in the hospitality industry: a research study on the impact of gender on the turnover intentions of highly educated employees. The International Journal of Human Resource Management, 21(1), 144-162, doi:10.1080/09585190903466954.

[18] A.B. Bakker and S. Albrecht, "Work engagement: current trends", Career Development International, Vol. 23 Issue: 1, pp.4-11,

[19] M. Behery, S. Abdallah, M. Parakandi and S. Kukunuru, "Psychological contracts and intention to leave with mediation effect of organizational commitment and employee satisfaction at times of recession", Review of International Business and Strategy, Vol. 26 Issue: 2, pp.184-203, 2016.

[20] S. van den Heuvel, C. Freese, R. Schalk and M. van Assen, "How change information influences attitudes toward change and turnover intention", Leadership \& Organization Development Journal, Vol. 38 No. 3, pp. 398-418, 2017

[21] Z. Xiong, J. Ye, and P. Wang, "Psychological Contract And Turnover Intention Of Dispatched Employees: Mediating Effects Of Job Satisfaction And Organizational Commitment," Revista de cercetare interventie social, vol. 56, pp. 19-43, 2017.

[22] C.J.A.-M. Shapiro, S. Pereira Costa, W. Doden and C. Chang, "Psychological Contracts: Past, Present, and Future," Annual Review of Organizational Psychology and Organizational Behavior, 2018 .
[23] M.E. Soares and P. Mosquera, "Fostering work engagement: The role of the psychological contract," Journal of Business Research, 2019.

[24] D.M. Rouseau, "The 'problem' of the psychological contract considered," Journal of organizational Behavior, Vol. 19, Issue S1 pp. 665-671, 1998.

[25] W.A. Kahn, "Psychological Conditions of Personal Engagement and Disengagement at Work," Academy of Management Journal, vol. 33, no. 4, pp. 692-724, 1990.

[26] W.B. Schaufeli, M. Salanova, V. González-romá and A.B. Bakker, "The Measurement of Engagement and Burnout: A Two Sample Confirmatory Factor Analytic Approach,” Journal of Happiness Studies, vol. 3, no. 1, pp. 71-92, 2002.

[27] W.B. Schaufeli and A.B. Bakker, "Job demands, job resources, and their relationship with burnout and engagement: a multi-sample study," Journal of Organizational Behavior, vol. 25, no. 3, pp. 293-315, 2004.

[28] M.E. Soares and P. Mosquera, "Fostering work engagement: The role of the psychological contract," Journal of Business Research, 2019.

[29] M.P. Leiter and A.B. Bakker, Work engagement: An emerging concept in occupational health psychology. A Handbook of essential theory and research, NY: Psychology press, 2010.

[30] P. Costa, A.M. Passos and A.B. Bakker, "The work engagement grid: predicting engagement from two core dimensions", Journal of Managerial Psychology, Vol. 31 Issue: 4, pp.774-789, 2016.

[31] S. Albrecht, E. Breidahl, and A. Marty, "Organizational resources, organizational engagement climate, and employee engagement," Career Development International, vol. 23, no. 1, pp. 67-85, 2018.

[32] C. Sheehan, T.L. Tham, P. Holland and B. Cooper, "Psychological contract fulfillment, engagement and nurse professional turnover intention", International Journal of Manpower. Emerald Publishing Limited 0143-7720, 2019.

[33] P.M. Bal, P.G.W. Jansen, M.E.G. van der Velde, A.H. de Lange, and D.M. Rousseau, "The role of future time perspective in psychological contracts: A study among older workers," Journal of Vocational Behavior, vol. 76, no. 3, pp. 474-486, 2010

[34] L.W. Porter and R.M. Steers, "Organizational, work, and personal factors in employee turnover and absenteeism," Psychological Bulletin, vol. 80, no. 2, pp. 151-176, 1973.

[35] V. Kadiresan, M.H. Selamat, S. Selladurai, C.S.Ramendran, R.K.M.H Mohamed, "Performance Appraisal and Training and Development of Human Resource Management Practices (HRM) on Organizational Commitment and Turnover Intention," Asian Social Science, Vol. 11, No. 24, pp. 162-176, 2015.

[36] S.P. Robbins and T.A. Judge, Organizational Behavior, 15th ed., Pearson Prentice 1, Upper Saddle River, New Jersey: Pearson Prentice Hall 2013.

[37] X. Duan, X. Ni, L. Shi, L. Zhang, Y. Ye, H. Mu,... and Y. Wang, "The impact of workplace violence on job satisfaction, job burnout, and turnover intention: the mediating role of social support," Health and Quality of Life Outcomes, vol. 17, no. 1, 2019.

[38] J.R.B. Halbesleben and A.R. Wheeler, "The relative roles of engagement and embeddedness in predicting job performance and intention to leave," Work \& Stress, vol. 22, no. 3, pp. 242-256, 2008.

[39] R.J. Blomme, A. van Rheede, and D.M. Tromp, "The use of the psychological contract to explain turnover intentions in the hospitality industry: a research study on the impact of gender on the turnover intentions of highly educated employees," The International Journal of Human Resource Management, vol. 21, no. 1, pp. 144-162, 2010.

[40] G.P. De Bruin and C.M. Henn, "Dimensionality of the 9-Item Utrecht Work Engagement Scale (UWES-9)," Psychological Reports, vol. 112, no. 3, pp. 788-799, 2013.

[41] V. Gupta, U.A. Agarwal, and N. Khatri, "The relationships between perceived organizational support, affective commitment, psychological contract breach, organizational citizenship behavior and work engagement," Journal of Advanced Nursing, vol. 72, no. 11, pp. 28062817,2016 
[42] W.B. Schaufeli, A.B. Bakker and M. Salanova, "The Measurement of Work Engagement With a Short Questionnaire," Educational and Psychological Measurement, vol. 66, no. 4, pp. 701-716, 2006.

[43] M. Fishbein and M.C. Yzer, "Using Theory to Design Effective Health Behavior Interventions," Communication Theory, 32, pp.164-183, 2003.

[44] C. Timms, P. Brough, M. O'Driscoll, T. Kalliath, O.L. Siu, C. Sit, and D. Lo, "Flexible work arrangements, work engagement, turnover intentions and psychological health," Asia Pacific Journal of Human Resources, vol. 53, pp. 83-103, 2014.

[45] J.L. Arbuckle, G.A. Marcoulides, and R.E. Schumacker, "Full information estimation in the presence of incomplete data," Adv. Struct. Equ. Model. Issues Tech., vol. 243, p. 277, 1996.
[46] D. Ulrich, Human resources Champion .The next agenda for adding Value and delivering results. Massachusetts. Harvard Business School Press, 1987.

[47] D.M. Rousseau and M.M. Greller, Human resource practices: Administrative contract makers. Human Resource Management, vol. 33, no. 3, pp. 385-401, 1994.

[48] J.B. Barney and P.M. Wright, "On becoming a strategic partner: The role of human resources in gaining competitive advantage," Human Resource Management, vol. 37, no. 1, pp. 31-46, 1998.

[49] P.M. Bal, D.S. Chiaburu, and I. Diaz, "Does Psychological Contract Breach Decrease Proactive Behaviors? The Moderating Effect of Emotion Regulation," Group \& Organization Management, vol. 36, no. 6, pp. 722-758, 2011. 